\title{
NOVEL METHOD FOR FIRE RETARDANCY OF COTTON FABRICS COATED BY SPINACH LEAF EXTRACT ASSISTED BY CORONA DISCHARGE PLASMA
}

Metode Baru Pembuatan Kain Katun Tahan Api dengan Pelapisan Ekstrak Daun

Bayam Menggunakan Plasma Pijar Corona

\author{
Valentinus Galih Vidia Putra ${ }^{1}$, Andrian Wijayono ${ }^{1}$, dan Juliany Ningsih Mohamad ${ }^{2}$ \\ ${ }^{1}$ Program Studi Magister Rekayasa Tekstil dan Apparel, Politeknik STTT Bandung, Jalan Jakarta No. 31, \\ Bandung, 40272. \\ ${ }^{2}$ Program Studi Fisika, Universitas Nusa Cendana Kupang, Jalan Adi Sucipto Penfui, Kupang, 85001
}

\section{Correspondency}

Email : valentinus@kemenperin.go.id

$\begin{array}{ll}\text { Manuscript Entry } & : 28 \text { Mei } 2020 \\ \text { Revision } & : 15 \text { Oktober } 2020 \\ \text { Approved } & : 26 \text { Oktober } 2020\end{array}$

Keywords : plasma, spinach leaf extract, fire retardant properties

Kata kunci: plasma, ekstrak daun bayam, sifat tahan api

\section{ABSTRACT}

The application of material physics in the functional textile field has been widely applied, one of them is plasma technology. In this research, the fire retardant properties have been developed on cotton fabric textile using spinach leaf extract and commercial fire retardant resin using plasma technology pre-treatment. The properties of flame-retardant was applied to the cotton fabric with the help of atmospheric-pressure plasma method using a tip-cylinder electrode to improve absorbency time of spinach leaf extract. The cotton fabric used had undergone bleaching and mercerization process. In this research, two types of methods have been carried out, namely the immersion method on the commercial fire retardant resin substance with atmospheric pressure plasma pre-treatment and the immersion method on spinach leaf extract with atmospheric pressure plasma treatment. The fire retardant properties were tested using the standard method of fire retardant ASTM D6413-08, vertical method. In this research, atmospheric-pressure plasma treatment with a time variation of 2 minutes and 4 minutes has been carried out. The results showed that the cotton fabric treated with the immersion method on spinach leaf extract and atmospheric pressure plasma pre-treatment hava better fire retardant and absorbency time properties. It has also been found that the lenght of plasma exposure time on cotton fabrics will affect the fabric's fire retardant properties.

\section{ABSTRAK}

Aplikasi fisika material dalam bidang tekstil fungsional telah banyak diterapkan, salah satunya adalah teknologi plasma. Pada penelitian ini, sifat tahan api telah dikembangkan pada material kain katun menggunakan ekstrak daun bayam dan resin tahan api komersial dengan perlakuan pendahuluan menggunakan teknologi plasma. Peningkatan sifat tahan api telah diterapkan pada kain katun dengan bantuan metode plasma tekanan atmosfer dengan elektroda lancip-silinder yang berfungsi untuk meningkatkan daya serap ekstrak daun bayam. Kain katun yang digunakan adalah kain katun yang telah mengalami proses pemutihan dan merserisasi. Dalam penelitian ini, dua jenis metode telah dilakukan, yaitu metode perendaman pada zat resin tahan api dengan pra-perlakuan plasma tekanan atmosfer dan metode perendaman pada ekstrak daun bayam dengan perlakuan plasma tekanan atmosfer. Penilaian sifat tahan api diuji menggunakan metode standar metode vertikal fire retardant 
clKh Dinamika Kerajinan dan Batik: Majalah Ilmiah. Vol. 37 No. 2, Desember 2020, Hal. 207 - 218

ASTM D6413-08. Dalam penelitian ini, dilakukan perlakuan plasma tekanan atmosfer dengan variasi waktu 2 menit dan 4 menit. Hasil penelitian menyatakan bahwa kain katun yang diperlakukan dengan metode perendaman pada ekstrak daun bayam dan pra-perlakuan plasma tekanan atmosfer memiliki sifat tahan api dan waktu serap yang lebih baik. Selain hal tersebut, Berdasarkan hasil penelitian juga dapat disimpulkan bahwa durasi paparan plasma akan mempengaruhi sifat tahan api dari kain katun.

\section{INTRODUCTION}

According to (Putra \& Wijayono, 2019), application of physics in the field of textiles is increasingly found in various textile processes starting from fiberto yarn process, cloth fabrication process, and the finishing process. In the finishing process, the application of physics can be found in an in-depth study of the application of plasma. According to (Shishoo, 2007), (Putra \& Wijayono, 2019) and (Murti \& Putra, 2020) Plasma finishing/coating refers to the deposition of a thin coating (in nanometers) onto the substrates or fabric. In thin-layer coating process, plasma is used to change the nano surface of the material and also to increase absorption and bonding capacity of it. Improved quality of this coating can be achieved by using a plasma generator device such as plasma corona discharge in combination with a liquid as a coating material. The liquid can be chosen according to the targeted functionality. Applications include, for example, oleophobic properties, fire retardant, or antibacterial properties.

(Rauscher, Perucca, \& Buyle, 2010) state that in the field of textiles, fabrics can be obtained from organic materials (such as silk, cotton) and also synthetic materials (such as polyester fabrics). Fabric construction can be made by using knitting or weaving techniques or even non-woven methods. The main problem of fabric and polymer-based organic materials is the nonfire retardant properties of these materials which could potentially cause dangers (Basak, Samanta, \& Chattopadhyay, 2014). Natural cellulose fibres such as cotton and silk are examples of nonfire retardant materials (Horrocks, 1983) (Horrocks, 2008; Horrocks, 2019) (Miller, Martin, Meiser, \& Gargiullo, 1976) (Parmar \& Chakraborty, 2001). Possible dangers arising from the characteristic of cloth (highly flammable, difficult to absorb liquid, etc.) are more common in many textile materials, such as clothing and household apparatus (Horrocks, 2008). Based on some reports, about $20 \%$ of fires at home caused by textile materials (textiles as the first item on fire) were occurred in European countries in 1998 and about $50 \%$ of deaths caused by these fires (The Goverment Statistical Office, 1997) (A.R.Horrocks \& price, 2001) (The Associated Press, 1997) (The Associated Press, 1997).

Efforts to improve fire retardant properties in textile materials using plasma technology have been expressed by several researchers (Errifai, Jama, Bras, Delobel, \& Gengembre, 2004) (Horrocks, 2019) (Horrocks, Flame retardant/retardant textile coatings and laminates. , 2008) (Miller, Martin, Meiser, \& Gargiullo, 1976) (Palaskar, Desai, \& Shukla, 2015) (Shahidi, 2013) (Shahidi \& Ghoranneviss, 2013). Some researchers have used plasma as one method to apply fire retardant coatings on the surface of materials (Errifai, Jama, Bras, Delobel, \& Gengembre, 2004) (Shahidi, 2013) (Palaskar, Desai, \& Shukla, 2015) (Miller, Martin, Meiser, \& Gargiullo, 1976) There are several ways to improve fire retardant properties of textile materials, such as fibre mixing techniques (Miller et al., 1976); coating techniques (Horrocks, 2008) (Horrocks, 2019) ; plasma techniques (Shahidi, 2013) (Palaskar, Desai, \& Shukla, 2015) ; and polymer grafting techniques 
(Errifai, Jama, Bras, Delobel, \& Gengembre, 2004).

Plasma is the $4^{\text {th }}$ material composed of ionized gas substances (Shishoo, 2007) (Putra \& Wijayono, 2019) . Plasma has properties similar to gasses, which do not have volume and shape (Shishoo, 2007). In textile production process, plasma can be used for several applications, including to modify the hydrophilic properties of a material; increase adhesion power; improve dye ability; addition of anti-dirty, antibacterial and retardant properties; use of sterilization applications; and improvement of anti-drag on wool fibre (Amril, 2015) (Putra \& Wijayono, 2019). According to some researchers, plasma can be categorized as a solution of industrial problems in the energy and environmental fields. Plasma process has been known for its waterless characteristic because of the dry process, so it can be considered as a solution to the problem of waste (Rauscher, Perucca, \& Buyle, 2010) (Sjaifudin \& Sitohang, 2015) (Sjaifudin, Widodo, Muhlisin, $\&$ Nur, 2014). Some examples of industrial sectors that apply plasma technology include the textile industry, polymers, boards, paper, ceramics, metals, medical, inorganic and biomaterial materials, and the chemical industry (Shishoo, 2007). Although the use of plasma technology in textile sector has proven to show good results, but the slow development of plasma technology in Indonesia and the ignorance of the industry regarding the use of plasma technology make the utilization of this technology in said industry very rare.

The application of plasma technology as an effort to improve the fire retardant properties of cotton fabric has been successfully carried out by several researchers (Shahidi, 2013) (Shahidi \& Ghoranneviss, 2013). The process of plasma nitrogen in cotton fabric material has been shown to increase in fire retardant properties, with an increase in the char yield parameter of $6.8 \%$ and LOI of 3.3 (Shahidi \& Ghoranneviss, 2013). it shows an increase in fire retardant properties by 4 times for the treatment of plasma nitrogen without nano clay on cotton fabrics (Shahidi \& Ghoranneviss, 2013) . The fire retardant properties could be associated with the construction of cationic groups on cotton fabrics, due to particle changes on the surface of cellulose fibres, observed and examined by FTIR (Shahidi, 2013). In other studies, plasma processes have been carried out to improve the fire retardant properties of cotton woven fabric materials (Shahidi \& Ghoranneviss, 2013). Based on the research results of some researchers (Shahidi \& Ghoranneviss, 2013) ; (T.T.Yen, Wang, \& W.j.Guo, 2013) (Yen, T.Wang, \& Guo, 2012) (Wang, Han, \& W.Ke, 2006); (Huang, Yang, Wang, \& Gao, 2012); (Nazaré, Kandola, \& A. R. Horrocks, 2006) ; (Thirumal, Khastgir, Singha, Manjunath, \& Naik, 2009) the plasma process has succeeded in producing cotton fabric material that is fire-retardant, with an increment of the char yield parameter to $10.10 \%$ and LOI of 5 . The combined plasma process and the application of nano clay shows an increment in fire retardant properties by 5 times than the previous studies (Shahidi \& Ghoranneviss, 2013)

Spinach leaf extract has been known to add fire retardant properties to cotton fabric (Basak, Samanta, \& Chattopadhyay, 2014) . The application of spinach leaf extract on cotton fabric has been shown to increase LOI parameters to 12 from (Basak, Samanta, \& Chattopadhyay, 2014) Increasing of the LOI value affects the total burning with afterglow time of cotton fabric. With increasing concentration of spinach leaf extract, the burning with flame time could be reduced and the burning with afterglow time could be increased. Basak (Basak, Samanta, \& Chattopadhyay, 2014) defined flame time or the burning with flame time as the duration from when the 
fabric is first burned until it's extinguished, while coal time is defined as the duration from when the fires goes out until it's extinguished.

(Basak, Samanta, \& Chattopadhyay, 2014) explained that with the addition of spinach extract onto the fabric, the burning with flame time decreased significantly even to zero (with a duration of time before treatment was $60 \mathrm{~s}$ and after treatment is zero), whereas burning with afterglow or after flame stop has a tendency to rise (with before treatment of $0 \mathrm{~s}$ and after treatment of $400 \mathrm{~s}$ ) with horizontal flammability has a tendency to increase. It has also been found that the addition of spinach leaf extract to cotton fabric also decreases the total heat produced by $22 \%$ in the combustion process (Basak, Samanta, \& Chattopadhyay, 2014). The content of metal salts, silicates and water molecules are substances that contribute to the fire retardant properties produced by the spinach leaf extract material (Basak, Samanta, \& Chattopadhyay, 2014). The EDX analysis results show that the spinach leaf extract that has been applied to cotton fabric contains $33.54 \%$ C element, $57.28 \% \mathrm{O}$ element, $7.78 \% \mathrm{Na}$ element, $0.46 \% \mathrm{Mg}$ element, $0.21 \% \mathrm{Si}$ element, $0.14 \% \mathrm{Cl}$ element, $0.13 \% \quad \mathrm{~K}$ element, and $0.16 \% \mathrm{Ca}$ element. The content of nutrients in spinach plants namely $\mathrm{Zn}$ is a hygroscopic material when exposed to heat (fire). When the $\mathrm{Zn}$ element in spinach extract is exposed to heat (fire), it will be decomposed by the reaction,

$$
\mathrm{ZnCl}_{2} \cdot \mathrm{H}_{2} \mathrm{O} \rightarrow \mathrm{ZnCl}(\mathrm{OH})+\mathrm{HCl}+\mathrm{H}_{2} \mathrm{O}
$$

By heating, Magnesium element will form chloride-free radicals that can stop the flame. In this study, two types of fire retardant materials were used, such as fire retardant resin and spinach leaf extract. In this study, two methods were carried out, namely the immersion method on the fire retardant resin substance with atmospheric pressure plasma pre-treatment, and the immersion method on spinach leaf extract with atmospheric pressure plasma treatment. Based on some previous research, the application of plasma pretreatment by using a new type of tipcylinder electrode to increase the absorption and adhesion of spinach leaf extract has not been done by many researchers researchers (Shahidi \& Ghoranneviss, 2013) ; (T.T.Yen, Wang, \& W.j.Guo, 2013) (Yen, T.Wang, \& Guo, 2012) (Wang, Han, \& W.Ke, 2006); (Huang, Yang, Wang, \& Gao, 2012); (Nazaré, Kandola, \& A. R. Horrocks, 2006) ; (Thirumal, Khastgir, Singha, Manjunath, \& Naik, 2009). In this research, the plasma treatment is expected to enhance the absorption and adhesion properties of spinach leaf extract as well as to improve the fire retardant properties.

\section{METHODOLOGY}

In this research, a sample of textile was used in the form of plain-woven fabric made from $100 \%$ cotton with a surface density of $200 \mathrm{~g} / \mathrm{m}^{2}$. Woven fabric made from cotton was a fabric that has undergone a process of mercerization and bleaching before. Cotton fabric had a specification of weft density of 30 strands/inch and warp density of 40 strands/inch, with $\mathrm{Ne} 125$ warp yarn numbers and Ne1 30 weft thread numbers.

Spinach leaf extract material was obtained from fresh spinach leaf. The spinach leaf extract was then filtered and prepared to be applied to cotton woven fabrics and compared with the commercial fire retardant resin Leguard 700 obtained from the market.

Tip-cylinder configured plasma devices were generated using a maximum DC source up to $5 \mathrm{kV}$. Figure 1 shows the scheme of the tip-cylinder plasma device used in this study. Point electrodes were 
used as positive electrodes, whereas solid cylindrical electrodes act as negative electrodes. The distance between the electrodes used was $3 \mathrm{~cm}$. Point electrodes consist of 3 taper metals connected in series with a distance of $2.5 \mathrm{~cm}$ each bolt. Figure 2 shows a picture of the plasma device used in this study. The presence of plasma could be observed when there was a glowing violet light in the space between the active electrodes and passive electrodes. Figure 3 shows the construction of a plasma in the region between active electrodes and passive electrodes. The drying and curing process was carried out using a stenter machine which was set at temperature of $130^{\circ} \mathrm{C}-150^{\circ} \mathrm{C}$. In this study, stenter machine is a machine or apparatus for stretching or stentering fabrics. The purpose of the stenter machine was to bring the length and width to pre determined dimensions and also for heat setting and for applying finishing chemicals. The main function of the stenter was to stretch the fabric and to recover the uniform width of the fabric. The heating machine was used in the process of soaking the fabric in resin solution and spinach leaf extract solution and was set at a temperature of $100^{\circ} \mathrm{C}$. After the plasma process had been completed, an FTIR analysis was carried out on a cotton fabric produced by the plasma process using the Spectra Shimadzu FTIR device.

This research was conducted on a laboratory scale, namely variations in the treatment time of plasma treatment and immersion, as well as the influence of types of fire retardant substances. In this study, two types of methods were carried out, namely the immersion method on the fire retardant resin substance with atmospheric pressure pre-treatment (method A) and the immersion method on spinach leaf extract with atmospheric pressure pre-treatment (method B). Plasma pre-treatment was carried out at a voltage of $3 \mathrm{kV}$ using atmospheric gas media and had a temperature range of 27-28oC. FTIR analysis was carried out on cotton fabric that was given plasma pre-treatment. FTIR analysis was carried out with the aim of observing changes in functional groups on cotton fabrics and their relation to the construction of hydroxyl groups on the surface of cotton fabrics. Using the method of fire retardant vertical method. The parameters observed in the fire retardant test include burning with flame time, coal time and charcoal length. Fireproof tests were carried out to evaluate the fire retardant properties of each sample resulting from the proposed method.

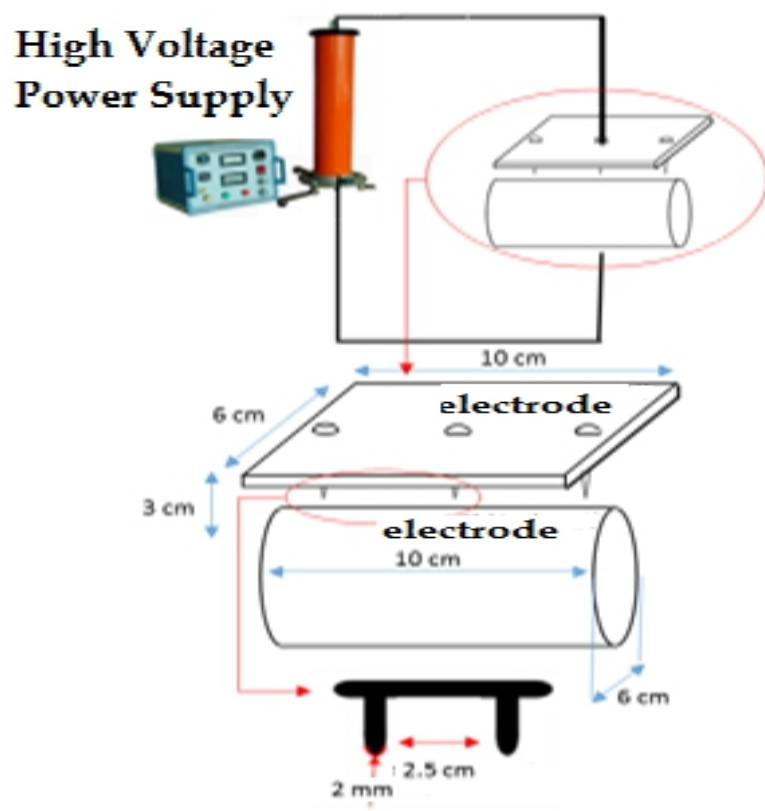

Figure 1 Plasma device with tip-cylinder configuration with a maximum voltage of $5 \mathrm{kV}$ 


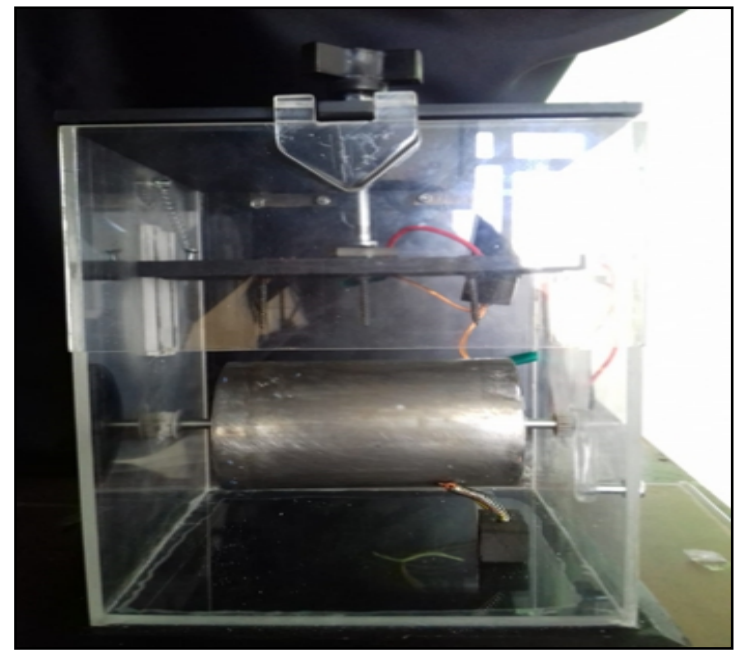

Figure2 Tip-cylinder corona discharge plasma device with a maximum voltage of $5 \mathrm{kV}$

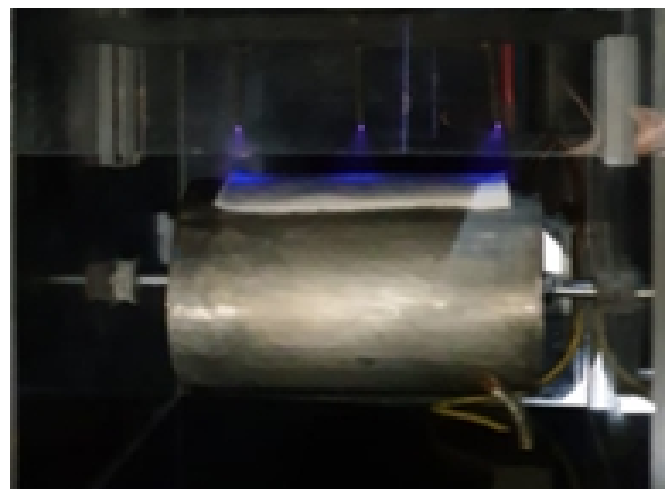

Figure3 Plasma formed in the area between active and passive electrodes

The Plasma-Immersion Method of fire retardant Resin was carried out through a pre-treatment method carried out using an atmospheric pressurized process at a voltage of $3 \mathrm{kV}$ at an ambient temperature of $27-28^{\circ} \mathrm{C}$. Two variations of the plasma treatment time were used, namely 2 minutes and 4 minutes. Cotton fabric without plasma treatment was also used in this method to determine the effect of plasma treatment on the resulting fire retardant properties. Immersion process was carried out sequentially after the plasma treatment process was complete. The process of soaking cotton fabric on fire retardant is carried out for 1 hour at boiling temperature. The drying process was carried out at $130^{\circ} \mathrm{C}$ for 5 minutes. The washing process was carried out at a series of stages of this method. Plasma-Soaking method of spinach leaf extract was done through the method of pre-treatment using plasma carried out in the same way with other methods. Plasma treatment at different times was carried out at 2 minutes and 4 minutes duration. The soaking process was done after the pre-treatment process using plasma was complete. The immersion method was carried out on a heating device for 1 hour. After the soaking process was finished, the drying and curing process was carried out on the fabric in sequence. The last process was the process of washing cotton fabrics that have been given treatment. In this study, several parameters related to fire retardant fabric absorption properties were observed, such as absorption time, flame time, ember time and charcoal length. The parameters observed in this study include the characteristics of the flame time, coal time, and the length of the charcoal of each cotton was woven fabric sample using the ASTM D6413-08 vertical method of fire retardant standard test methods. The effect of plasma duration, types of fire retardant substances and the method of application on the fire retardant properties were observed. FTIR analysis was carried out to determine changes in the functional group of cotton textile material from the plasma treatment.

\section{RESULTS AND DISCUSSIONS Water Drop Test}

The water drop test was carried out on a sample of $10 \times 6 \mathrm{~cm}^{2}$ cotton fabric, a plain- 
woven fabric made from $100 \%$ cotton with the surface density of $200 \mathrm{~g} / \mathrm{m}^{2}$. Cotton fabric has a specification of feed density of 30 strands/inch and warp density of 40 strands/inch, with the number of warp $\mathrm{Ne} 1$ 25 and number of $\mathrm{Ne} 1$ weft 30. Plasma radiation exposure was carried out to modify cotton fabric through plasma treatment for 2 minutes and 4 minutes with air as a plasma medium. Direct testing was carried out after the completion of the fabric surface modification process using a plasma generator by measuring the length of time through a stopwatch and drop test with a pipette. The results of the absorption time test after surface modification with plasma were then compared with the absorbency time of cotton fabric without plasma treatment (as shown in Table 1)

Table 1. Time absorbing parameters of cotton fabric by plasma and without plasma exposure

\begin{tabular}{|c|c|c|}
\hline $\begin{array}{l}\text { Radiation time } \\
\text { (minutes) }\end{array}$ & $\begin{array}{l}\text { Plasma } \\
\text { voltage } \\
(\mathbf{k V})\end{array}$ & $\begin{array}{l}\text { Absorption } \\
\text { time } \\
\text { (s) }\end{array}$ \\
\hline $\begin{array}{l}\text { O(without } \\
\text { plasma) }\end{array}$ & 0 & 11 \\
\hline 2 & 3 & 5 \\
\hline 4 & 3 & 2 \\
\hline
\end{tabular}

Based on drops test experiments for $100 \%$ cotton fabric with plasma exposure for 2 minutes and 4 minutes, the optimal fabric absorption time is 4 minutes with fabric absorption time of 2 seconds.

Modifications of Functional Groups of Cotton Fabrics with Plasma

Figure 4 shows the FTIR spectra of a $100 \%$ cotton-based woven fabric treated under different conditions, respectively. FTIR-ATR analysis can help study the interaction between cotton fabric and plasma species (Kan \& Lam, 2018). FTIR-ATR spectra showed the results that the plasma treatment had given changes to the surface chemical structure of cotton cellulose fibres.

The absorption intensity at 3400-3200 $\mathrm{cm}^{-1}(\mathrm{O}-\mathrm{H})$ of the plasma cotton fabric is slightly higher than that of the non-plasma fabric, which indicates the presence of additional $\mathrm{O}-\mathrm{H}$ stretches after atmospheric plasma pre-treatment (ian, et al., 2011) (Samanta, Jassal, \& Agrawal, 2009) Peak intensity in the region of $1657-1605 \mathrm{~cm}^{-1}$ (C $=0$ ) increases and small peaks emerge after plasma treatment, which shows the effect of oxidation on the surface of the fabric after undergoing plasma (ian, et al., 2011) (Samanta, Jassal, \& Agrawal, 2009). Besides, in the band area of $1330-1000 \mathrm{~cm}^{-}$ 1 , a higher peak of absorbance was obtained on cotton fabric that was given plasma treatment. The band area $1330-1000 \mathrm{~cm}^{-1}$ is associated with oxygen-containing groups from stretching $\mathrm{C}-\mathrm{O}$. Increasing the $\mathrm{C}=\mathrm{O}$ band and stretching the $\mathrm{C}-\mathrm{O}$ confirm that there are additional polar groups on the surface of the fibre after plasma (ian, et al., 2011) (Samanta, Jassal, \& Agrawal, 2009). This shows that plasma treatment can increase the hydrophilicity of cotton fabrics. The peak value of $2980-2800 \mathrm{~cm}^{-1}$ is related to the stretching of the methylene group ($\mathrm{CH} 2-)$ in the long chain of alkyl which shows the presence of wax in the cotton cellulose material (Chung, lee, \& Choe, 2004). The level of absorbance in the value of 2980$2800 \mathrm{~cm}^{-1}$ was reduced after the cotton fabric material was given plasma treatment. This shows that there is a decrease in the amount of wax content on the surface of the cellulose material. 


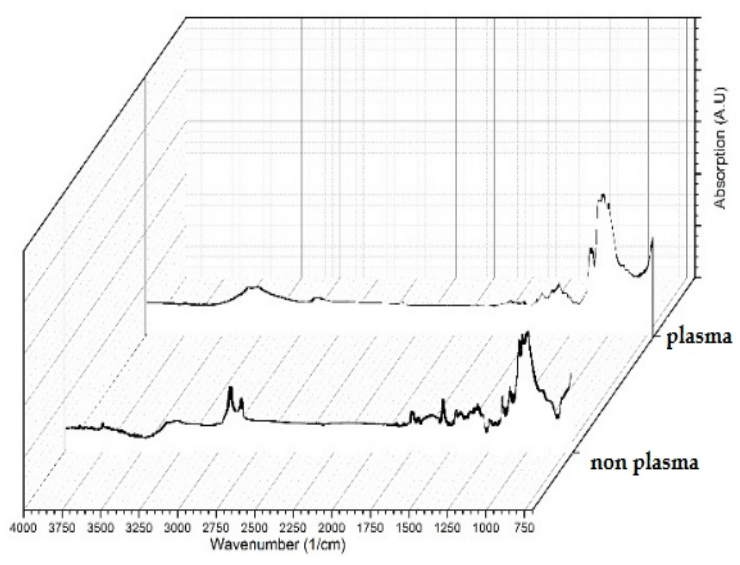

Figure 4 FTIR spectra of $100 \%$ cotton-based woven fabrics which are treated in plasma and non-plasma conditions, respectively.

The increased hydrophilicity of cotton fabrics could be confirmed based on the results of FTIR that have been carried out. Based on this, fabric samples that had been given plasma exposure had a higher absorption of the fire retardant substances that were given. Increased absorption can be caused by the increasing of the number of hydroxyl groups as well as the decreasing of the amount of wax content in the cellulose material that was given plasma treatment. This could be confirmed based on the results of testing the fire retardant properties in Table 2. Samples that had undergone plasma treatment had a shorter flame time and had a longer charcoal length compared to without plasma treatment. This is related to the increased adhesive properties and absorption of cotton fabrics after radiation by plasma (Shishoo, 2007, Putra\& Wijayono, A).

\section{Flame-Retardant Cotton Fabric}

The test method of fire retardant could be used through the British standard 3119; 1959, or based on the AATCC Test Method 34-1969. In this study, the method used in this test is based on the ASTM D6413-08 vertical method of fire retardant standard test methods. In this study, the results of testing the fire retardant properties of cotton fabric obtained from several different treatment methods had been obtained. The variations in the refinement of fire retardant properties that were carried out include variations in the fire retardant used, the method of application of fire retardant, and the addition of the plasma process in the pre-treatment stage. Table 2 shows the results of data testing the fire retardant properties of several variations of the treatment that has been done. In this study, the test results had successfully shown that there was an influence of the type of application method used on the fire retardant properties.

Table 2. Test results of fire retardant properties with parameters of burning time, coal time and charcoal length on fabric samples that have been treated

\begin{tabular}{lllll}
\hline $\begin{array}{l}\text { Variation } \\
\text { of } \\
\text { treatment }\end{array}$ & $\begin{array}{l}\text { Plasma } \\
\text { treatm } \\
\text { ent } \\
\text { durati } \\
\text { on } \\
\text { (minut } \\
\text { es) }\end{array}$ & $\begin{array}{l}\text { Burni } \\
\text { ng } \\
\text { time } \\
\text { (s) }\end{array}$ & $\begin{array}{l}\text { Coal } \\
\text { time } \\
\text { (s) }\end{array}$ & $\begin{array}{l}\text { Charcoa } \\
\text { I length } \\
\text { (cm) }\end{array}$ \\
\hline & 0 & 25.27 & 21.37 & 0 \\
A & 2 & 26.31 & 21.51 & 0 \\
& 4 & 27.57 & 22.1 & 0 \\
\hline & 0 & 11 & 84 & 11.5 \\
& 4 & 11.02 & 82 & 13.2 \\
& 2 & 10.02 & 81 & 13.5 \\
\hline
\end{tabular}

*The test was carried out using the standard method of testing the vertical fire retardant properties of ASTM D6413-08

This study also conducted a comparison between different fire retardant substances, namely between Leguard 700 
fire retardant resin (treatment A) and spinach leaf extract (treatment B). fire retardant properties resulting from different substances can be observed from the data obtained.

Basak (Basak, Samanta, \& Chattopadhyay, 2014) said that the burning time or the burning with the flame time is the time when the fabric is first burned and the fire is extinguished and coal time is the time when the time from fires goes out until the coal extinguished. In this study, spinach extract showed better fire retardant properties than the commercial flameretardant resin. It can be seen from the shorter burning time and coal time, also greater length of charcoal for fabric samples with spinach leaf extract compared to commercial fire retardant resin (Basak, Samanta, \& Chattopadhyay, 2014) .The heating factor in the immersion process also contributes to opening the pores of cellulose fibre, so that the contents of the spinach extract easily enter the fibre. Based on the observational data, samples of spinach extract fabric that had been treated with the plasma method for 4 minutes and impregnation for an hour have a burning time of 10.02 seconds with a coal time of 81 seconds and a charcoal length of $13.5 \mathrm{~cm}$. It has been found that the addition of spinach leaf extract to cotton fabric also decreases the total heat produced by decreasing the burning and coal time also increasing the charcoal length. Plasma treatment caused lower burning with flame time and lower coal time and also greater charcoal length for B (Spinach leaf extract), so the plasma treatment increased the fire retardancy, but not for A (commercial fire retardant substances).

Basak, Samanta \& Chattopadhyay (2014) explained that with the addition of spinach extract onto the fabric, the burning with flame time decreased significantly with horizontal flammability has a tendency to increase. The decreasing of burning with flame time and increasing the charcoal length and coal time can be caused by the increased absorption properties of fabric which is treated by plasma according to Table1 so that the mineral salt content of spinach extract enters the fibre easily. This finally results in better fire resistance. The presence of mineral salts can slow down the thermal decomposition of cellulose because it can help produce more charcoal (indicated by the charcoal length $13.5 \mathrm{~cm}$ ) and non-combustible gases such as $\mathrm{CO}_{2}$ and $\mathrm{H}_{2} \mathrm{O}$. This gas can dilute flammable gases such as levoglucosan and pyroglucosan which are produced during the pyrolysis of cellulose in the combustion process.

In this study we have also found that based on drops test experiments for $100 \%$ cotton fabric with plasma exposure for 2 minutes and 4 minutes, the optimal fabric absorption time is 4 minutes with fabric absorption time of two seconds, so we can get more extract that can be coated on fabric as well as we can improve the fire retardant of the fabric.

\section{CONCLUSIONS AND SUGGESTIONS} Conclusion

This research has shown the spinach leaf extract properties as fire retardant material on cotton fabric with the plasma pre-treatment method. Spinach leaf extract assisted by plasma had been succeed in showing better fire retardant properties on cotton fabrics compared to commercial fire retardant resin. Based on observational data, cotton fabric that have been treated by plasma pre-treatment have a better fire retardant cotton fabric compared to commercial fire retardant substances.

\section{Suggestions}

Further research is expected to be investigated regarding modeling to determine the relationship of input voltage, 
plasma treatment time for modification of fabric properties and fire retardancy

\section{AUTHORS CONTRIBUTION}

Valentinus Galih Vidia Putra conceived of the presented idea. Valentinus Galih Vidia Putra and Juliany Ningsih Mohamad developed the theory and corona discharged plasma. Valentinus Galih Vidia Putra and Andrian Wijayono verified the analytical methods. Juliany Ningsih Mohamad encouraged Valentinus Galih Vidia Putra to investigate and supervised the findings of this work. All authors discussed the results and contributed to the final manuscript.

\section{ACKNOWLEDMENT}

The author would like to thank Dr. Mohamad Widodo for sharing the knowledge of plasma technology and also the Department of Textile Engineering Polytechnic STTT Bandung and the Physics Laboratory of Universitas Nusa Cendana for supporting this research activity so that this research can be completed well.

\section{REFERENCES}

A.R.Horrocks, \& price, D. (2001). FlameretardantMaterials. England: Woodhead Publishing.

Amril, H. (2015). Teknologi Plasma untuk Pengolahan Air. Bandung: Institut Teknologi Bandung.

ASTM International. (2008). Standard Test Method for Flame Resistance of Textiles (Vertical Test). West Conshohocken: ASTM International.

Basak, S., Samanta, K. K., \& Chattopadhyay, S. (2014). Fire-retardantproperty of cotton fabric treated with herbal extract. The Journal of The Textile Institute, 13381347 doi: 10.1080/00405000.2014.995456.

Chung, C., lee, M., \& Choe, E. (2004). Characterization of cotton fabric scouring by FT-IR ATR spectroscopy. Carbohydr. Polym, 417-420.
Errifai, I., Jama, C., Bras, M. L., Delobel, R., \& Gengembre, L. (2004). Elaboration of a fire-retardantcoating for polyamide- 6 using cold plasma polymerization of a fluorinated acrylate. Surface and Coatings Technology, 297-301.

Horrocks, A. (1983). An introduction to the burning behaviour of cellulosic fibres. $J$. Soc.Dyers.Col, 191-197.

Horrocks, A. (2008). Flame retardant/retardant textile coatings and laminates. . Advances in Fire-retardantMaterials, 159-187, doi:10.1533/9781845694701.1.159.

Horrocks, A. (2019). Smart flame-retardant. textile coatings and laminates, 205-236.

Horrocks, A., Tune, M., \& D.Price. (1989). The Burning Behaviour of Textiles and Its Assessment by Oxygen-Index Method, Textile Prog, 18.

Huang, G., Yang, J., Wang, X., \& Gao, J. (2012). Nanoclay, intumescent flame retardants, and their combination with chemical modification for the improvement of the flame-retardant properties of polymer nanocomposites.

Macromolecular Research, 2.

ian, L., Nie, H., Chatterton, N., Branford-White, C., Y. Qiu, \& Zhu, L. (2011). Helium/oxygen atmosphericpressure plasma jet treatment for hydrophilicity improvement of grey cotton knitted fabric. . Appl. Surf. Sci., 257, 7113-7118.

Kan, C. W., \& Lam, C. (2018). Atmospheric Pressure Plasma Treatment for Grey Cotton Knitted Fabric. Polymers, 10(1), 53. doi:10.3390/polym10010053.

Miller, B., Martin, J., Meiser, C., \& Gargiullo, M. (1976). The Flammability of PolyesterCotton Mixtures. Textile Research Journal, 46(7), pp. 530538..doi:10.1177/004051757604600714.

Murti, \& Putra. (2020). Studi Pengaruh Perlakuan Plasma Terhadap Sifat Material Antibakteri Kain Kassa Menggunakan Minyak Atsiri (Zingiber Officinale Rosc). Jurnal Teori dan Aplikasi Fisika 8 (1), 6976.

Nazaré, S., Kandola, B. K., \& A. R. Horrocks. (2006). Flame-retardant unsaturated polyester resin incorporating nanoclays. 
clKh Dinamika Kerajinan dan Batik: Majalah Ilmiah. Vol. 37 No. 2, Desember 2020, hal. 207 - 218

Polymers for Advanced Technologies, 17(4), pp. 294-303..doi:10.1002/pat.687.

Palaskar, S. S., Desai, A. N., \& Shukla, S. R. (2015). Development of multifunctional cotton fabric using atmospheric pressure plasma and nano-finishing. The Journal of The Textile Institute, 107(3), pp. 405412..doi:10.1080/00405000.2015.103493 2.

Parmar, M. S., \& Chakraborty, M. (2001). Thermal and Burning Behavior of Naturally Colored Cotton. Textile Research Journal, 71(12), pp 10991102..doi:10.1177/004051750107101211.

Putra, V. G., \& Wijayono, A. (2019). Suatu Studi Awal Modifikasi Sifat Pembasahan Pada Permukaan Kain Tekstil Poliester 100\% Menggunakan Teknologi Plasma Pijar Korona. Prosiding Seminar Nasional Fisika (E-Journal), vol. 8, pp. 15-20.

Rauscher, H., Perucca, M., \& Buyle, G. (2010). Plasma Technology for Hyperfunctional Surfaces: Food, Biomedical, and Textile Applications, 1 ed, . New Jersey: WileyVCH. ISBN: 9783527326549.

Samanta, K., Jassal, M., \& Agrawal, A. (2009). Improvement in water and oil absorbency of textile substrate byatmospheric pressure cold plasma treatment. Surf. Coat. Technol., 203, 1336-

1342.http://dx.doi.org/10.1016/j.surfcoat. 2008.10.044.

Shahidi, S. (2013). Novel method for ultraviolet protection and flame retardancy of cotton fabrics by low-temperature plasma. Cellulose, 21(1), pp. 757768.doi:10.1007/s10570-013-0127-9.

Shahidi, S., \& Ghoranneviss, M. (2013). Effect of Plasma Pretreatment Followed by nano clay Loading on Flame-retardant Properties of Cotton Fabric. Journal of Fusion Energy, 33(1), 8895..doi:10.1007/s10894-013-9645-6.

Shishoo, R. (2007). Plasma Technologies for Textiles, . London: Woodhead Publishing Series in Textiles.ISBN: 9781420044508.

Sjaifudin, A., \& Sitohang, K. (2015). Rancang Bangun Prototip Mesin Plasma Tekstil Lucutan Korona Pada Tekanan Atmosfir Skala Laboratorium . Arena Tekstil, vol. 3, no. $\quad 1_{1 \prime} \quad \mathrm{pp} 25-36$. http://dx.doi.org/10.31266/at.v30i1.1946. Sjaifudin, A., Widodo, M., Muhlisin, Z., \& Nur, M. (2014). Modifikasi Permukaan Bahan Tekstil Dengan Plasma Lucutan Korona. Proceeding Indonesian Textile Conference Semnasteks 2014 (pp. pp. 122,). Bandung: Politeknik STTT Bandung.

T.T.Yen, Wang, H., \& W.j.Guo. (2013). Synergistic effect of aluminum hydroxide and nano clay on flame retardancy and mechanical properties of EPDM composites. . Journal of Applied Polymer Science, 130(3), pp. 20422048.doi:10.1002/app.39394.

The Associated Press. (1997, April 16). Fire in Mecca Kills Pilgrims In The Tent Camps. The New York Times, . New York.

The Associated Press. (1997, April 16). Tent City Fire Kills Hundreds of Pilgrims. Washington.

The Goverment Statistical Office. (1997). Fire Statistics. London: The Goverment Statistical Office.

Thirumal, M., Khastgir, D., Singha, N. K., Manjunath, B. S., \& Naik, Y. P. (2009). Effect of a nano clay on the Mechanical, Thermal and Flame-retardant Properties of Rigid Polyurethane Foam. Journal of Macromolecular Science, Part A, 46(7), pp. 704-712.

Tsafack, M. J., \& Levalois-GruÈtzmacher, J. (2006). ,Plasma-induced graftpolymerization offlameretardantmonomers onto PAN fabrics. Surface and Coatings Technology,200, 3503-3510.

Wang, Z., Han, E., \& W.Ke. (2006). fire retardant effect of nano clay on intumescent nanocomposite coatings. Journal of Applied Polymer Science, 103(3), pp. 1681-1689..doi:10.1002/app.25096.

Yen, Y. Y., T.Wang, H., \& Guo, W. (2012). Synergistic flame-retardanteffect of metal hydroxide and nano clay in EVA composites. Polymer Degradation and Stability, 97(6), pp. 863 869..doi:10.1016/j.polymdegradstab.201 2.03.043 
IKh Dinamika Kerajinan dan Batik: Majalah Ilmiah. Vol. 37 No. 2, Desember 2020, Hal. 207 - 218 